\title{
ANALISIS PENGARUH PROFITABILITAS, UKURAN PERUSAHAAN, DAN KOMPENSASI RUGI FISKAL TERHADAP TAX AVOIDANCE (STUDI EMPIRIS PADA PERUSAHAAN MANUFAKTUR SUB SEKTOR INDUSTRI LOGAM YANG TERDAFTAR DI BURSA EFEK INDONESIA PERIODE 2013-2017)
}

\author{
Pratiwi Nursehah 1) \\ Program Studi Akuntansi Fakultas Ekonomi \\ Universitas Krisnadwipayana \\ Email : pratiwinursehah21@gmail.com \\ Heni Yusnita ${ }^{2)}$ \\ Program Studi Akuntansi Fakultas Ekonomi \\ Universitas Krisnadwipayana \\ Email : hyusnita@gmail.com
}

\begin{abstract}
This study aimed to test and provide empirical evidence of the influence of profitability, firm size and fiscal lost compensation on tax avoidance. This study classified as causative research. The population in this study was manufacturing companies listed on Indonesian Stock Exchange in 2013 until 2017. The sample was chosen by purposive sampling method and after reduces with several criteria, 13 firms are determined as samples. Data used was secondary data obtained from www.idx.co.id. Data was analyzed by using a linear regression analysis with help a program named SPPS version 25. The results showed that : 1) profitability has a significant effect on tax avoidance. 2) firm size has a significant effect on tax avoidance. 3) fiscal lost compensation has significant effect on tax avoidance. The tests are based on confidence level of $95 \%$, and an error rate of $5 \%$.
\end{abstract}

Keywords: fiscal lost compensation, firm size, profitability, tax avoidance

\section{PENDAHULUAN}

Pembangunan nasional merupakan salah satu kegiatan pemerintah yang berlangsung secara terus menerus dan berkesinambungan yang bertujuan untuk meningkatkan kesejahteraan masyarakat baik materil maupun spiritual. Untuk dapat merealisasikan tujuan tersebut, pemerintah harus memperhatikan masalah pembiayaan pembangunan suatu bangsa agar bisa mandiri dalam pembiayaan pembangunan yaitu dengan cara menggali sumber pendapatan pemerintah. Sumber pendapatan pemerintah berasal dari pendapatan pajak dan pendapatan non pajak. Pajak adalah pungutan wajib yang dibayar rakyat untuk negara dan akan digunakan untuk kepentingan pemerintah dan masyarakat umum. Rakyat yang membayar pajak tidak akan merasakan manfaat dari pajak secara langsung, kerena pajak digunakan untuk kepentingan umum, bukan untuk kepentingan pribadi. Pajak merupakan salah satu sumber dana pemerintah untuk melakukan pembangunan, baik pemerintah pusat maupun pemerintah daerah. 
Sedangkan bagi perusahaan, pajak merupakan suatu beban atau biaya yang akan mengurangi laba bersih atau penghasilan seseorang maupun perusahaan. Disatu sisi penghindaran pajak diperbolehkan, tapi disisi lain penghindaran pajak tidak diinginkan (Setiyono, 2012).

Menurut pemerintah hingga akhir tahun 2015 penerimaan pajak gagal menyentuh target Rp. 1.294,3 triliun dalam Anggaran Pendapatan dan Belanja Negara (APBN-P) 2015 dan penerimaan pajak pada tahun 2016 hanya mencapai Rp. 1.098, 5 triliun atau 84,9 persen dari target. Tidak tercapainya target penerimaan pajak tersebut dapat disebabkan adanya tindakan wajib pajak yang meminimalkan pajaknya melalui berbagai cara, salah satunya adalah tax avoidance. Tax Avoidance merupakan bagian dari tax planning yang dilakukan dengan tujuan meminimalkan pembayaran pajak. Menurut Lim (2011) mendefinisikan pengertian tax avoidance sebagai penghemat pajak yang timbul dengan memanfaatkan ketentuan perpajakan yang dilakukan secara legal untuk untuk meminimalkan kewajiban pajak.

Secara hukum pajak tax avoidance tidak dilarang meskipun seringkali mendapat sorotan yang kurang baik dari kantor pajak karena dianggap memiliki konotasi yang negatif. Meski tax avoidance bersifat legal, dari pihak pemerintah tetap tidak menginginkan hal tersebut.

Fenomena penghindaran pajak di Indonesia, terdapat 750 perusahaan Penanaman Modal Asing (PMA) yang ditengarai melakukan penghindaran pajak dengan melaporkan rugi dalam waktu 5 tahun berturut-turut dan tidak membayar pajak, umumnya perusahaan tersebut bergerak di bidang manufaktur dan pengolahan bahan baku (Bapennas, 2015).

Berikut ini grafik tax avoidance yang terjadi pada perusahaan manufaktur sub sektor logam pada tahun 2013 - 2017.

\section{Tax Avoidance}

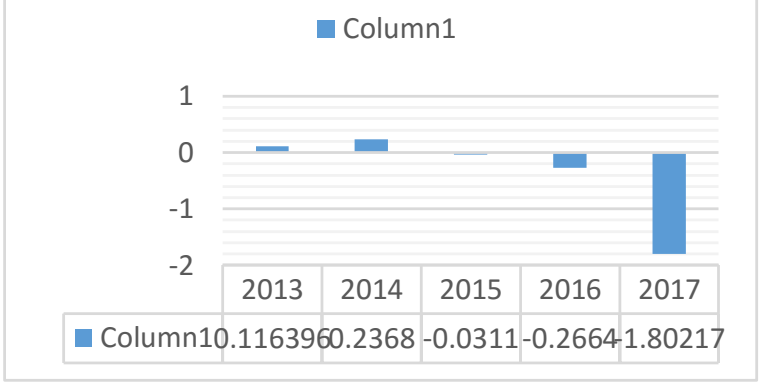

Sumber : Data IDX, Data diolah

Gambar 1. Tax Avoidance Perusahaan Manufaktur Sub Sektor Industri Logam Tahun 2013 - 2017

Berdasarkan data grafik diatas, dapat dilihat bahwa rata - rata perusahaan manufaktur sub sektor industri logam yang terdaftar di BEI pada tahun 2013 - 2017 perusahaan yang melakukan tax avoidance mengalami fluktuasi. Indikator tax avoidance atau penghindaran pajak adalah CETR atau Cash Effective Tax Rate. CETR adalah mengakomodasikan jumlah kas pajak yang dibayarkan saat ini oleh perusahaan. Jika nilai CETR semakin rendah akan membuktikan bahwa perusahaan yang melakukan tax avoidance semakin besar, sebaliknya jika nilai CETR semakin tinggi maka tax avoidance yang dilakukan oleh perusahaan akan semakin kecil. Nilai CETR berkisar lebih dari 0 dan kurang dari 1. (Warsini, 2014).

Ada beberapa faktor yang mempengaruhi tax avoidance, diantaranya yaitu : kompensasi rugi fiskal, corporate social responsibility (CSR), profitabilitas, ukuran perusahaan, leverage, kepemilikan institusional. Beberapa faktor tersebut memiliki hubungan dan pengaruh terhadap tax avoidance yang tidak konsisten.

ROA merupakan pengukur untuk keuntungan bersih yang diperoleh dari seberapa besar perusahaan menggunakan asset. Semakin tinggi nilai ROA, maka semakin tinggi keuntungan 
perusahaan sehingga semakin baik pengelolaan asset suatu perusahaan. Semakin tinggi nilai ROA, maka semakin besar juga laba yang diperoleh perusahaan.

Ketika laba yang diperoleh membesar, maka jumlah pajak penghasilan akan meningkat sesuai dengan peningkatan laba perusahaan sehingga kecenderungan untuk melakukan tax avoidance yang dilakukan oleh perusahaan juga akan meningkat. Perusahaan yang memiliki profitabilitas yang tinggi akan memiliki kesempatan untuk memposisiskan diri dalam tax planning yang akan mengurangi jumlah beban kewajiban membayar pajak. Pada penelitian terdahulu yang dilakukan oleh Rinaldy (2015) yang berjudul pengaruh profitabilitas, ukuran perusahaan dan kompensasi rugi fiskal terhadap tax avoidance pada perusahaan manufaktur berpengaruh signifikan positif terhadap tax avoidance, hal ini menunjukkan bahwa semakin tinggi profitabilitas maka akan semakin tinggi pula kemampuan perusahaan untuk menghasilkan keuntungan.

Ukuran perusahaan adalah suatu skala yang dapat mengklasifikasikan perusahaan dengan cara yaitu total aset, jumlah penjualan, jumlah tenaga kerja, dan lain - lain. Ukuran perusahaan menunjukkan kestabilan dan kemampuan perusahaan untuk melakukan aktivitas ekonominya. Semakin besar ukuran suatu perusahaan maka semakin menjadi pusat perhatian dari pemerintah dan akan menimbulkan kecenderungan bagi para manajer perusahaan untuk berlaku patuh (compliances) atau menghindari pajak (tax avoidance) dalam perpajakan (Sari, 2013).

Tax Avoidance yang dilakukan oleh perusahaan dapat di pengaruhi oleh faktor keuangan yaitu kompensasi rugi fiskal dimana perusahaan akan diberikan keringanan untuk membayar pajak bila perusahaan mengalami kerugian dalam satu periode akuntan. Dalam hal ini, kerugian yang dialami perusahaan akan dikompensasikan selama lima tahun kedepan dan laba kena pajak perusahaan selama lima tahun akan digunakan untuk mengurangi jumlah dari kompensasi kerugian sehingga perusahaan terhindar dari adanya beban pajak (Martani, 2010).

Kompensasi Rugi fiskal merupakan proses peralihan kerugian dari satu periode ke periode lainnya yang menunjukkan perusahaan yang sedang merugi tidak akan dibebani pajak. Sari (2014) mengatakan "Perusahaan yang merugi pada periode sebelumnya dapat meminimalkan beban pajak pada periode berikutnya. Kerugian yang ditanggung perusahaan dapat dikompensasikan kepada laba yang diterima selama 5 tahun berikutnya, sehingga pajak yang harus dibayarkan dapat diminimalkan karena angka laba yang terutang menjadi kecil".

Tujuan penelitian ini adalah Untuk mengetahui apakah Profitabilitas, Ukuran Perusahaan, dan Kompensasi Rugi Fiskal berpengaruh terhadap Tax Avoidance pada perusahaan manufaktur sub sector industri logam yang terdapat di BEI periode 2013-2017.

\section{METODE PENELITIAN Populasi}

Data yang digunakan dalam penelitian ini adalah data sekunder perusahaan manufaktur yang tercatat di Bursa Efek Indonesia (BEI) tahun 2013 - 2017.

\section{Sampel}

Teknik pengambilan sampel pada penelitian ini menggunakan purposive sampling. Purposive sampling merupakan salah satu teknik non random sampling dimana peneliti menentukan pengambilan sampel dengan cara menetapkan ciri khusus yang sesuai dengan penelitian. Pengambilan sampel data dilakukan dengan teknik purposive sampling yang memenuhi kriteria - kriteria sebagai berikut :

1. Memilih perusahaan manufaktur sub sektor industri logam yang terdaftar di Bursa Efek Indonesia pada tahun 2013 - 2017.

2. Menerbitkan dan mempublikasikan laporan tahunan dan laporan keuangan audited selama tahun 2013 - 2017.

3. Menerbitkan laporan keuangan yang berakhir pada tanggal 31 desember dan menggunakan mata uang rupiah.

4. Memiliki data yang lengkap dan sesuai dengan variabel yang diteliti 


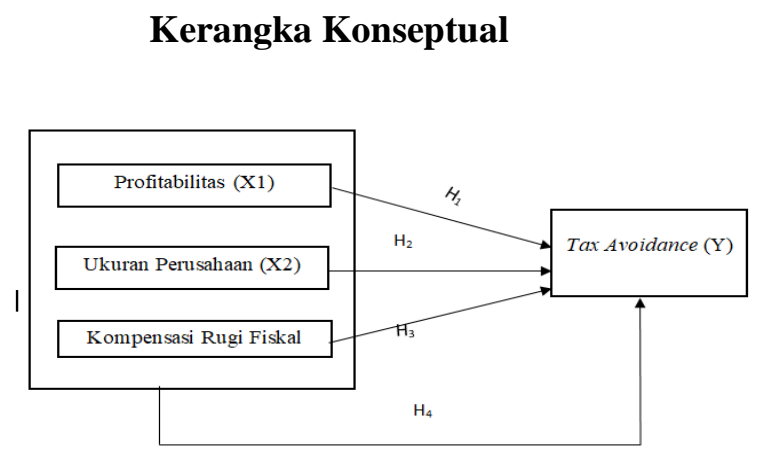

$\mathrm{H}_{1}$ : Profitabilitas berpengaruh terhadap Tax Avoidance

$\mathrm{H}_{2}$ : Ukuran Perusahaan berpengaruh terhadap Tax Avoidance.

$\mathrm{H}_{3}$ : Kompensasi Rugi Fiskal berpengaruh terhadap tax avoidance

$\mathrm{H}_{4}$ : Profitabilitas, Ukuran Perusahaan dan Kompensasi Rugi Fiskal berpengaruh terhadap tax avoidance

Tabel 1. Operasional Variabel

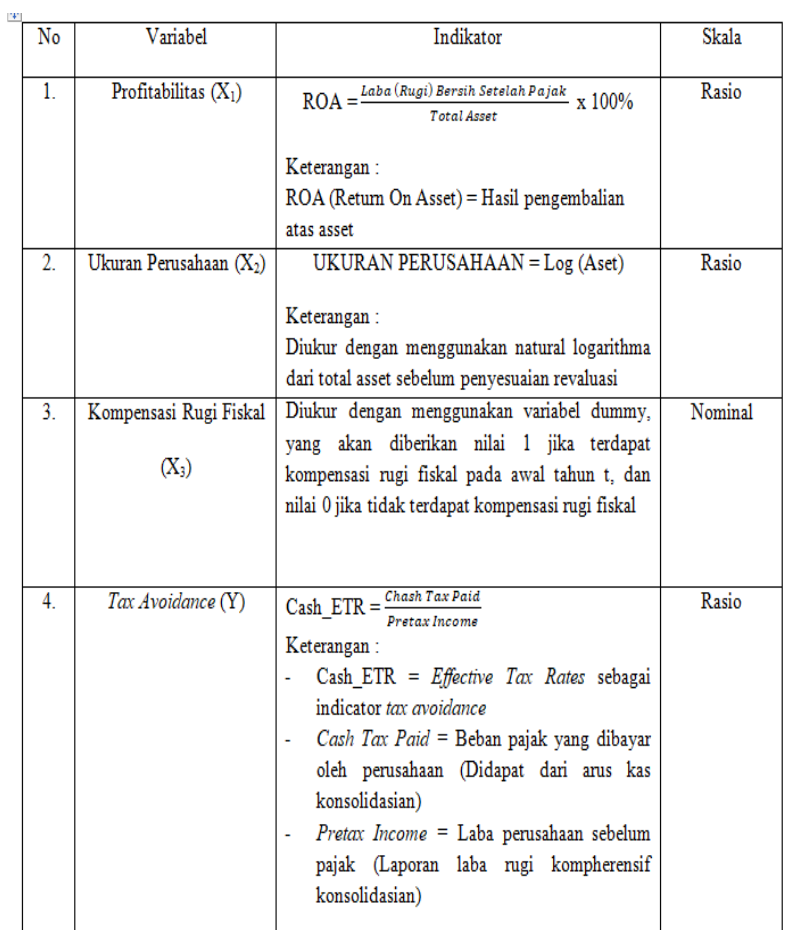

Sumber : Data diolah penulis (2019)

\section{HASIL PENELITIAN DAN PEMBAHASAN}

Hasil statistik deskriptif dari masingmasing variabel dilihat dari nilai minimum, nilai maksimum, nilai rata-rata (mean), dan standar deviasi untuk semua perusahaan selama periode penelitian yaitu tahun 2013 - 2017 disajikan dalam tabel berikut ini:

Tabel 2. Hasil Analisis Statistik Deskriptif

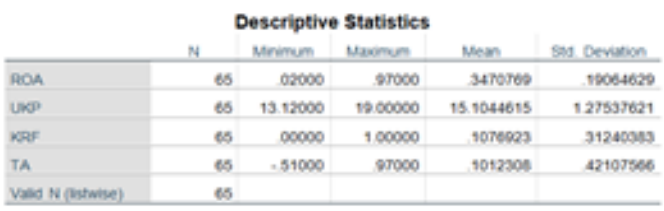

Berdasarkan tabel diatas hasil analisis dengan menggunakan statistik deskriptif terhadap variabel profitabilitas menunjukan nilai minimum sebesar .02000 yaitu PT Jakarta Kyoei Stell Works Tbk (JKSW) dan nilai maximum sebesar .97000 yaitu PT Asahimas Flat Glass Tbk (AMFG) . Dari hasil deskriptif juga 
menunjukan standar deviasi sebesar .19064629 sedangkan nilai rata-rata sebesar .3470769 .

Hasil analisis dengan menggunakan statistik deskriptif terhadap variabel ukuran perusahaan menunjukan nilai minimum sebesar 13.12000 yaitu Alaska Industrindo Tbk (ALKA) dan nilai maximum sebesar 19.00000 yaitu Steel Pipe Industry Of Indonesia Tbk (ISSP). Nilai rata-rata sebesar 15.1044615 dan standar deviasi sebesar 1.27537621. Hasil analisis dengan menggunakan statistik deskriptif terhadap variabel kompensasi rugi fiskal dengan metode perhitungan dummy menunjukan ada 13 perusahaan yang mempunyai nilai minimum sebesar ,00000 dan nilai maximum sebesar 1,00000 yaitu PT Jakarta Kyoei Stell Works Tbk (JKSW). Nilai rata-rata sebesar .1076923 dan standar deviasi sebesar .31240383. Hasil analisis dengan menggunakan statistik deskriptif terhadap variabel tax avoidance menunjukan nilai minimum sebesar -.51000 yaitu Alaska Industrindo Tbk (ALKA) dan nilai maximum sebesar .97000 yaitu Alumindo Light Metal Industry Tbk (ALMI). Nilai rata-rata sebesar .1012308 dan standar deviasi sebesar .42107566 .

\section{Hasil Uji Hipotesis}

1. Hasil Analisis Regresi Berganda

Dalam penelitian ini digunakan tekhnik analisis regresi berganda, dimana analisis regresi berganda digunakan untuk meramalkan pengaruh dua atau lebih variabel prediktor (variabel bebas) terhadap suatu variabel kriterium (variabel terikat) atau untuk membuktikan ada atau tidaknya hubungan fungsional antara dua buah variabel bebas (X) atau lebih dengan sebuah variabel terikat $(\mathrm{Y})$. Berdasarkan data melalui program SPSS menghasilkan output data seperti dibawah ini:

Tabel 3. Hasil Uji Regresi Berganda

\begin{tabular}{|c|c|}
\hline \multirow{2}{*}{ Model } & $\begin{array}{c}\text { Unstandardized } \\
\text { Coefficients }\end{array}$ \\
\cline { 2 - 2 } (Constant) & B \\
ROA & .149 \\
& .269 \\
\hline
\end{tabular}

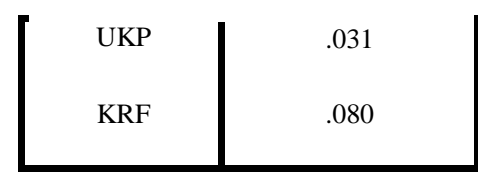

Berdasarkan tabel di atas maka data dalam penelitian ini dapat disusun dengan persamaan regresi berganda sebagai berikut :

$Y=-0.149+0.269 X_{1}+0.031 X_{2}+0.080 X_{3}+e$

Dari persamaan di atas dapat dilihat hubungan antara variabel independen yaitu profitabilitas, ukuran perusahaan dan kompensasi rugi fiskal terhadap variabel dependen yaitu tax avoidance, maka dapat dijelaskan sebagai berikut:

a. Nilai Konstanta yang diperoleh dari hasil uji diatas adalah sebesar -0.149. Hal ini menunjukkan jika tidak ada variabel bebas profitabilitas, ukuran perusahaan dan kompensasi rugi fiskal maka tax avoidance sudah tebentuk sebesar -0.149.

b. Koefisien $\beta_{1}$ untuk variabel profitabilitas (ROA)

Koefisen regresi ROA $\left(\mathrm{X}_{1}\right)$ sebesar 0.269, artinya apabila terjadi peningkatan ROA sebesar 1 persen, maka akan mempengaruhi peningkatan dalam TA sebesar 0.269 persen dengan asumsi jika variabel bebas lainnya bernilai tetap.

c. Koefisien $\beta_{2}$ untuk variabel Ukuran Perusahaan (UKP)

Koefisen regresi UKP $\left(\mathrm{X}_{2}\right)$ sebesar 0.031, artinya apabila terjadi peningkatan tingkat UKP sebesar 1 persen, maka akan mempengaruhi peningkatan dalam TA sebesar 0.031 persen dengan asumsi jika variabel bebas lainnya bernilai tetap.

d. Koefisien $\beta_{3}$ untuk variabel Kompensasi Rugi Fiskal (KRF)

Koefisen regresi KRF (X3) sebesar 0.080, artinya apabila terjadi peningkatan tingkat KRF sebesar 1 persen, maka akan mempengaruhi peningkatan dalam TA sebesar 0.080 persen dengan asumsi jika variabel bebas lainnya bernilai tetap.

Hasil Uji Parsial ( Uji statistik T ) 
Uji t digunakan untuk menguji secara parsial masing-masing variabel. Hasil uji t dapat dilihat pada tabel coefficients pada kolom sig (significance). Jika probabilitas nilai $\mathrm{t}$ atau signifikansi < 0,05, maka dapat dikatakan bahwa terdapat pengaruh yang signifikan antara variabel bebas terhadap variabel terikat secara parsial. Namun, jika probabilitas nilai $t$ atau signifikan > 0,05, maka dapat dikatakan bahwa tidak terdapat pengaruh yang signifikan antara masing-masing variabel bebas terhadap variabel terikat. Berdasarkan SPSS versi 22, hasil Uji T dapat dilihat pada tabel berikut ini :

\section{Tabel 4. Hasil Uji T Parsial}

\section{Profitabilitas (ROA)}

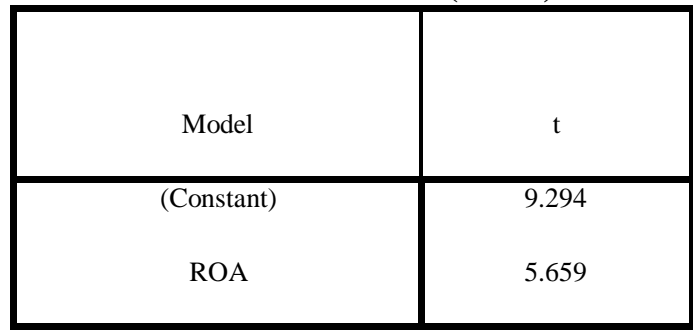

Ukuran Perusahaan (UKP)
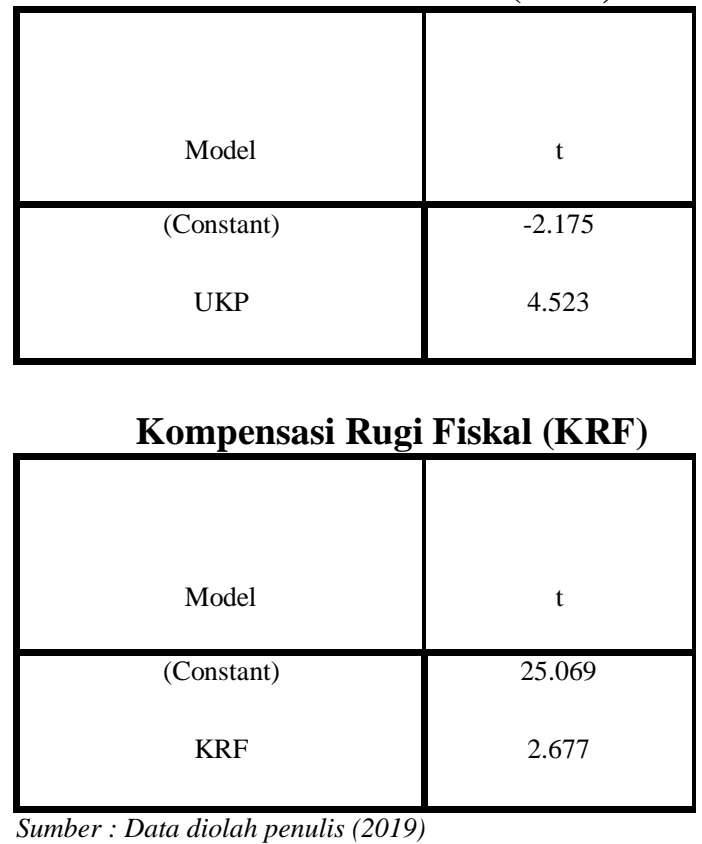

Dari hasil analisis regresi diatas menunjukkan bahwa nilai $t_{\text {hitung }}$ profitabilitas (ROA) lebih besar dari tabel yaitu 5,659 > $1,999624\left(\mathrm{t}_{\text {tabel }}=5 \%, \mathrm{df}=(65-3-1=61)\right.$. Dengan kondisi nilai signifikan sebesar 0,000 berada di bawah $0,05(0,000<0,05)$, maka hasil tersebut menunjukkan bahwa $\mathrm{H}_{1}$ diterima dan $\mathrm{H}_{0}$ ditolak yang berarti variabel profitabilitas secara parsial berpengaruh signifikan terhadap tax avoidance.

Nilai $t_{\text {hitung }}$ ukuran perusahaan (UKP) lebih besar dari tabel yaitu $4.523>1,999624$ $\left(\mathrm{t}_{\text {tabel }} \alpha=5 \%\right.$, df $=(65-3-1=61)$. Dengan kondisi nilai signifikan sebesar 0,000 berada di bawah $0,05(0,000<0,05)$, maka hasil tersebut menunjukkan bahwa $\mathrm{H}_{1}$ diterima dan $\mathrm{H}_{0}$ ditolak yang berarti variabel ukuran perusahaan secara parsial berpengaruh signifikan terhadap tax avoidance.

Nilai $t_{\text {hitung }}$ kompensasi rugi fiskal (KRF) lebih besar dari tabel yaitu $2.677>$ $1,999624\left(\mathrm{t}_{\text {tabel }}=5 \%, \mathrm{df}=(65-3-1=61)\right.$. Dengan kondisi nilai signifikan sebesar 0,000 berada di bawah $0,05(0,009<0,05)$, maka hasil tersebut menunjukkan bahwa $\mathrm{H}_{1}$ diterima dan $\mathrm{H}_{0}$ ditolak yang berarti variabel kompensasi rugi fiskal secara parsial berpengaruh signifikan terhadap tax avoidance.

\section{Hasil Uji Simultan ( Uji statistik F )}

Uji $F$ digunakan untuk menguji salah satu hipotesis di dalam penelitian yang menggunakan analisis regresi linear berganda dan uji $F$ digunakan juga untuk mengetahui pengaruh variabel bebas secara bersama-sama (simultan) terhadap variabel terikat. Penggunaan tingkat signifikansinya beragam, tergantung keinginan peneliti, yaitu 0,01 (1\%), 0,05 (5\%), dan $0,10(10 \%)$. Hasil uji $\mathrm{F}$ dilihat dalam tabel ANOVA pada kolom sig peneliti menggunakan taraf signifikansi 5\% $(0,05)$, jika nilai signifikan $<0,05$, maka dapat dikatakan terdapat pengaruh yang signifikan secara simultan antara variabel bebas terhadap variabel terikat. Namun, jika nilai signifikansi > 0,05 maka tidak terdapat pengaruh yang signifikan secara simultan antara variabel bebas terhadap variabel terikat. Berikut hasil output uji F yang peneliti lakukan menunjukkan bahwa nilai $\mathrm{F}_{\text {hitung }}$ sebesar 15,161 dengan tingkat signifikan sebesar 0,000. Nilai

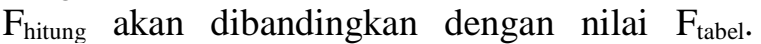
Nilai $\mathrm{F}_{\text {tabel }}$ pada tingkat kesalahan $\alpha=5 \%=(\mathrm{n}-\mathrm{k})$ 
; (k-1). Jumlah sampel (n) sebanyak 65 dan jumlah variabel penelitian (k) berjumlah 3 , jadi $\mathrm{df}=(65-3) ;(3-1)$ sehingga $\mathrm{F}_{\text {tabel }}$ pada tingkat kepercayaan $95 \%(\alpha=5 \%)$ adalah 2,755431. Jadi $F_{\text {hitung }}>F_{\text {tabel }}(15,161>2,755)$ dengan kondisi nilai signifikan sebesar 0,000 berada di bawah $0,05(0,000<0,05)$, yang berarti hasil tersebut menunjukkan bahwa profitabilitas, ukuran perusahaan dan kompensasi rugi fiskal secara simultan berpengaruh signifikan terhadap tax avoidance.

\section{Hasil Uji Koefisien Determinasi $\left(\mathbf{R}^{\mathbf{2}}\right)$}

Koefisien determinasi digunakan untuk mengetahui seberapa besar kemampuan variabel independen dalam menerangkan variabel dependen. Nilai determinasi terlihat dari nilai Adjusted $R$ Square. Hasil pengujian koefisien determinasi menjelaskan bahwa nilai $R^{2}=0.427$ artinya adalah $42,7 \%$ tax avoidance (TA) dapat dijelaskan oleh variabel profitabilitas (ROA), ukuran perusahaan (UKP) dan kompensasi rugi fiskal (KRF), sedangkan sisanya $57,3 \%$ dijelaskan variabel lain yang tidak diteliti.

\section{Pembahasan}

Penelitian ini dilakukan dengan tujuan untuk menemukan bukti empiris apakah terdapat pengaruh yang signifikan antara profitabilitas, ukuran perusahaan dan kompensasi rugi fiskal terhadap tax avoidance. Berdasarkan hasil penelitian uji demi uji diatas diperoleh jawaban mengenai perumusan masalah yang telah diuraikan pada bab sebelumnya sebagai berikut :

\section{Pengaruh Profitabilitas terhadap Tax Avoidance}

Hasil penelitian yang dilakukan menunjukan bahwa variabel profitabilitas yang diukur dengan return on asset (ROA) berpengaruh terhadap tax avoidance. Berdasarkan hasil pengujian pada tabel 9, profitabilitas menunjukkan nilai $t_{\text {hitung }}$ adalah sebesar 5,659 dengan nilai signifikansi sebesar 0,000 . Nilai t hitung lebih besar dari nilai t tabel $5,659>1,99$. Jadi dapat disimpulkan bahwa profitabilitas berpengaruh terhadap tax avoidance. Hasil penelitian ini sesuai dengan penelitian yang telah dilakukan oleh Ida Ayu Rosa Dewinta dan Putu Eri Setiawan (2016) yang menyatakan bahwa profitabilitas berpengaruh signifikan terhadap tax avoidance pada perusahaan manufaktur sub sektor industri logam yang artinya semakin tinggi profitabilitas, maka semakin tinggi pula tingkat tax avoidance suatu perusahaan yang disebabkan karena perusahaan dengan laba yang besar akan lebih leluasa untuk memanfaatkan celah terhadap pengelolaan beban pajaknya.

Beberapa peneliti yang melakukan penelitian di perusahaan manufaktur selain sub sektor industri logam menyatakan bahwa profitabilitas berpengaruh terhadap tax avoidance. Hasil penelitian dari yang dilakukan oleh Kurniasih dan Sari (2013) yang menyatakan bahwa profitabilitas berpengaruh secara signifikan terhadap tax avoidance. Hasil penelitian dari Annisa Fadilla (2015) menyatakan bahwa variabel profitabilitas berpengaruh negatif dan tidak signifikan terhadap tax avoidance. Hasil penelitian yang berbeda dan menyatakan bahwa profitabilitas berpengaruh negatif dan tidak signifikan terhadap tax avoidance disebabkan karena perbedaan tahun penelitian dan perbedaan sampel perusahaan manufaktur selain sub sektor industri logam yaitu menggunakan sub sektor campuran.

\section{Pengaruh Ukuran Perusahaan terhadap Tax Avoidance}

Hasil penelitian yang dilakukan menunjukan bahwa variabel ukuran perusahaan yang diukur dengan logaritma natural (LN) berpengaruh terhadap tax avoidance. Berdasarkan hasil pengujian pada tabel 9 ukuran perusahaan, didapat nilai $t_{\text {hitung }}$ sebesar 4,523 dengan nilai signifikan sebesar 0,000. Nilai t hitung lebih besar dari nilai t tabel 4,523 > 1,99. Jadi dapat disimpulkan bahwa ukuran perusahaan berpengaruh terhadap tax avoidance.

Hasil penelitian ini sesuai dengan penelitian Kurniasih dan Sari (2013), yang menyatakan bahwa ukuran perusahaan secara signifikan mempengaruhi terjadinya tax avoidance perusahaan manufaktur karena semakin besar ukuran perusahaan maka akan semakin rendah CETR yang dimilikinya karena perusahaan besar lebih mampu menggunakan sumber daya yang dimilkinya untuk membuat 
suatu perencanaan pajak yang baik (political power theory).

Beberapa peneliti yang melakukan penelitian di perusahaan manufaktur selain sub sektor industri logam menyatakan bahwa ukuran perusahaan berpengaruh terhadap tax avoidance. Hasil penelitian dari Viona Syukrina E Janrosl dan Dian Efriyenti (2018) menyatakan bahwa ukuran perusahaan berpengaruh signifikan terhadap tax avoidance. Sedangkan hasil penelitian ini tidak sesuai dengan penelitian Annisa Fadilla (2015) Nurfadilah, Mulyati, Purnamasari dan Niar (2016) yang menyatakan bahwa ukuran perusahaan tidak berpengaruh signifikan terhadap tax avoidance. Karena membayar pajak merupakan kewajiban perusahaan, sehingga baik perusahaan besar maupun kecil akan selalu dikejar oleh fiskus apabila melanggar ketentuan perpajakan. Hasil penelitian yang berbeda dan menyatakan bahwa ukuran perusahaan berpengaruh negatif dan tidak signifikan terhadap tax avoidance disebabkan karena perbedaan tahun penelitian dan perbedaan sampel perusahaan manufaktur selain sub sektor industri logam yaitu menggunakan sub sektor campuran.

\section{Pengaruh Kompensasi Rugi Fiskal terhadap Tax Avoidance \\ Hasil penelitian yang dilakukan} menunjukan bahwa variabel kompensasi rugi fiskal yang diukur dengan menggunakan variabel dummy berpengaruh terhadap tax avoidance. Berdasarkan hasil pengujian pada tabel 9 kompensasi rugi fiskal, didapat nilai thitung sebesar 2,677 lebih besar dari dengan nilai signifikan sebesar 0,009. Nilai t hitung lebih besar dari nilai t tabel 2,677> 1,99. Jadi dapat disimpulkan bahwa kompensasi rugi fiskal berpengaruh terhadap tax avoidance.

Hasil penelitian ini sesuai dengan penelitian Kurniasih dan Sari (2013), yang menyatakan bahwa ukuran perusahaan secara signifikan mempengaruhi terjadinya tax avoidance perusahaan manufaktur karena perusahaan yang merugi pada periode sebelumnya dapat meminimalkan beban pajak pada periode berikutnya. Kerugian yang ditanggung perusahaan dapat dikompensasikan kepada laba yang diterima selama 5 tahun berikutnya, sehingga pajak yang harus dibayarkan dapat diminimalkan karena angka laba yang terutang menjadi kecil. Hasil penelitian dari Waluyo (2014), Rinaldi (2015) menyatakan bahwa variabel kompensasi rugi fiskal berpengaruh negatif dan tidak signifikan terhadap tax avoidance. Hasil penelitian yang berbeda dan menyatakan bahwa kompensasi rugi fiskal berpengaruh negatif dan tidak signifikan terhadap tax avoidance disebabkan karena perbedaan tahun penelitian dan perbedaan sampel perusahaan manufaktur selain sub sektor industri logam yaitu menggunakan sub sektor campuran.

\section{Pengaruh Profitabilitas, Ukuran Perusahaan dan Kompensasi Rugi Fiskal terhadap Tax Avoidance}

Berdasarkan hasil pengujian hipotesis dengan menggunakan uji $F$, variabel profitabilitas, ukuran perusahaan dan kompensasi rugi fiskal secara simultan (bersama-sama) berpengaruh signifikan terhadap tax avoidance yang diukur dengan cash_etr pada perusahaan manufaktur yang terdaftar di bursa efek Indonesia (BEI). Ini berdasarkan nilai $F_{\text {hitung }}$ sebesar 15,161 dan nilai $F_{\text {tabel }}$ sebesar 2,755 sehingga $F_{\text {hitung }}>F_{\text {tabel }}$ dengan tingkat signifikan 0,000 lebih kecil dari pada taraf signifikan 0,05 , maka dapat disimpulkan bahwa $\mathrm{H}_{\mathrm{a}}$ diterima dan $\mathrm{H}_{0}$ ditolak yang berarti variabel profitabilitas ukuran perusahaan dan kompensasi rugi fiskal secara simultan berpengaruh signifikan terhadap tax avoidance.

\section{Keterbatasan Penelitian}

Peneliti memiliki keterbatasan dalam penelitian ini yang kemungkinan dapat menimbulkan ketidakakuratan pada hasil penelitian ini, diantaranya sebagai berikut :

1. Penelitian membatasi tahun observasi yaitu selama 5 tahun yang dimulai dari tahun 2013-2017.

2. Sampel yang digunakan adalah perusahaan manufaktur sub sektor logam yang terdaftar di Bursa Efek Indonesia tidak semua digunakan, yang digunakan yang mengalami laba rugi pada tahun 2013-2017. 
3. Sampel yang digunakan hanya 13 perusahaan yang memiliki kriteria dalam penelitian ini.

4. Data harus ditransformasikan agar dapat terdistribusi secara normal.

\section{KESIMPULAN DAN SARAN Kesimpulan}

Berdasarkan hasil penelitian dan pembahasan yang telah dijabarkan mengenai profitabilitas, ukuran perusahaan dan kompensasi rugi fiskal terhadap tax avoidance pada perusahaan manufaktur sub sektor logam yang terdaftar di Bursa Efek Indonesia pada tahun 2013-2017, penulis dapat menarik beberapa kesimpulan sebagai berikut :

1. Profitabilitas secara parsial berpengaruh signifikan terhadap tax avoidance pada perusahaan manufaktur sub sektor industri logam yang terdaftar di Bursa Efek Indonesia pada tahun 2013-2017. Hal ini ditunjukkan dari hasil perhitungan t-hitung sebesar 2,677 lebih besar dari pada nilai t-tabel sebesar 1,99 dengan nilai signifikansi yang berada dibawah 0,05 yaitu sebesar 0,009. Semakin tinggi profitabilitas, maka semakin tinggi pula tingkat tax avoidance suatu perusahaan yang disebabkan karena perusahaan dengan laba yang besar akan lebih leluasa untuk memanfaatkan celah terhadap pengelolaan beban pajaknya. Menurut Standar Akuntansi Keuangan (2009), indikator kinerja perusahaan terutama profitabilitas diperlukan untuk menilai perubahan potensial sumber daya ekonomi yang mungkin dikendalikan di masa depan. Prospek yang bagus akan menarik minat investor untuk berinvestasi dalam suatu perusahaan sehingga diperlukan pengungkapan yang lebih luas pada laporan tahunan perusahaan. Rasio profitabilitas menjadi bentuk penilaian terhadap kinerja manajemen dalam mengelola kekayaan perusahan yang ditunjukkan oleh laba yang dihasilkan.

2. Ukuran perusahaan secara parsial berpengaruh signifikan terhadap tax avoidance pada perusahaan manufaktur sub sektor industri logam yang terdaftar di Bursa
Efek Indonesia pada tahun 2013-2017. Hal ini ditunjukkan dari hasil perhitungan thitung sebesar 4,523 lebih besar dari pada nilai t-tabel sebesar 1,99 dengan nilai signifikansi yang berada dibawah 0,05 yaitu sebesar 0,000 . Penerapan ukuran perusahaan dalam manajer perusahaan besar cenderung melakukan pemilihan metode akuntansi yang menangguhkan laba yang dilaporkan dari periode sekarang ke periode mendatang guna memperkecil laba yang dilaporkan. Perusahaan besar lebih memiliki aktivitas operasi perusahaan yang lebih banyak dan rumit sehingga terdapat celah-celah untuk dimanfaatkan dalam keputusan tax avoidance. Semakin besar ukuran perusahaan biasanya informasi yang tersedia untuk investor dalam mengambil keputusan sehubungan dengan investasi saham yang ditanamkan dalam perusahaan tersebut semakin banyak.

3. Kompensasi rugi fiskal secara parsial berpengaruh signifikan terhadap tax avoidance pada perusahaan manufaktur sub sektor industri logam yang terdaftar di Bursa Efek Indonesia pada tahun 2013-2017. Hal ini ditunjukkan dari hasil perhitungan $\mathrm{t}$ hitung sebesar 2,677 lebih besar dari pada nilai t-tabel sebesar 1,99 dengan nilai signifikansi yang berada dibawah 0,05 yaitu sebesar 0,009. Perusahaan yang telah merugi dalam satu periode akuntan diberikan keringanan untuk membayar pajaknya. Kerugian tersebut dapat dikompensasikan selama lima tahun ke depan dan laba perusahaan akan digunakan untuk mengurangi jumlah kompensasi kerugian tersebut. Akibatnya, selama lima tahun tersebut, perusahaan akan terhindar dari beban pajak, karena laba kena pajak akan digunakan untuk mengurangi jumlah kompensasi kerugian perusahaan.

4. Profitabilitas, ukuran perusahaan dan kompensasi rugi fiskal secara simultan berpengaruh signifikan terhadap tax avoidance. Dapat dilihat dari nilai F hitung > F tabel yaitu 15,161>2,75 dengan tigkat signifikansi $0,000<0,05$. Hasil penelitian ini 
menunjukkan bahwa profitabilitas, ukuran perusahaan dan kompensasi rugi fiskal dapat mempengaruhi tax avoidance. Karena perusahaan besar akan lebih mampu menggunakan sumber daya yang dimilikinya untuk membuat suatu perencanaan pajak yang baik (political power theory).

\section{Saran}

Peneliti memiliki beberapa saran yang dapat dijadikan pertimbangan bagi penelitianpenelitian selanjutnya, antara lain :

1. Penelitian selanjutnya perlu menambahkan jangka waktu observasi lebih panjang untuk mendapatkan hasil yang lebih baik.

2. Menggunakan sampel yang lebih banyak agar hasil yang didapatkan semakin baik.

3. Menggunakan variabel independen yang baru untuk menambah atau menggantikan variabel independen yang digunakan dalam penelitian ini dan penelitian sebelumnya.

4. Penelitian selanjutnya diharapkan menggunakan alat ukur yang berbeda untuk mengukur tax avoidance.

\section{DAFTAR PUSTAKA}

Adriani. 2014. Teori Perpajakan, Jakarta: Salemba Empat.

Annisa, F., 2015. Pengaruh Return On Assets, Leverage, Corporate Governance, Ukuran Perusahaan Dan Kompensasi Rugi Fiskal Terhadap Tax Avoidance Pada Perusahaan Manufaktur Yang Terdaftar Di Bursa Efek Indonesia. Universitas Muhammadiyah Surakarta.

Ardyansyah, D., 2014. Pengaruh Size, Leverage, Profitability, Capital Intensity Ratio Dan Komisaris Independen Terhadap Effective Tax Rate (Etr). Semarang: Fakultas Ekonomika dan Bisnis Universitas Diponegoro.

Budiman. 2012. Pengaruh Karakter Eksekutif terhadap Penghindaran Pajak (Tax Avoidance). Jurnal. Universitas Islam Sultan Agung.

Cahyati. 2016. Pengaruh Profitabilitas Terhadap Penghindaran Pajak Dengan Kompensasi
Rugi Fiskal Sebagai Pemoderasi. Skripsi. Universitas Pamulang.

Hanafi. 2012. Pengaruh Profitabilitas, Kebijakan hutang, Kebijakan Deviden, Keputusan Investasi dan Kepemilikan Insider terhadap Nilai Perusahaan. Jurnal Ilmu Riset Akuntansi. Vol. 3 No. 4.

Kasmir. 2015. Analisis Laporan Keuangan. Jakarta: Rajawali Pers.

Kurniasih, Tommy dan Maria M. Ratna Sari. 2013. Pengaruh Return Turn On Asset (ROA), Leverage, Corporate Governance, Ukuran Perusahaan dan Kompensasi rugi Fiskal pada Tax Avoidance. Buletin Studi Ekonomi. 18 (1): h : $58-66$.

Lim, YD. 2011. Tax Avoidance, cost of debt and shareholder activism : Evidence from Korea”. Journal of Banking \&amp; Finance, $35: 456-470$.

Mardiasmo. 2013. Perpajakan. Yogyakarta: Penerbit Andi.

Muhardi. 2015. Analisis Laporan Keuangan Proyeksi dan Valuasi Saham. Jakarta: Salemba Empat.

Munawir. 2014. Analisa Laporan Keuangan. Yogyakarta: Liberty.

Ngadiman, Puspitasari,C., 2014. Pengaruh Leverage, Kepemilikan Institusional, Dan Ukuran Perusahaan Terhadap Penghindaran Pajak (Tax Avoidance) Pada Perusahaan Sektor Manufaktur Yang Terdaftar Di Bursa Efek Indonesia 2010 2012. Jurnal Akuntansi, Volume XVIII, No. 03, September 2014:408-421.

Nurfadilah, Mulyati. 2016. Pengaruh Leverage, Ukuran Perusahaan dan Kualitas Audit Terhadap Penghindaran Pajak. Skripsi. Fakultas Ekonomi. STIE Ahmad Dahlan Jakarta.

Puspitasari. 2016. Pengaruh Kompensasi Rugi Fiskal Dan Konservatisme Akuntansi, Kepemilikan Manajerial Dan Ukuran DewanKomisaris Terhadap Tax Avoidance. Skripsi. Fakultas Ekonomi dan Bisnis, Universitas Udayana Bali.

Rinaldi. 2015. Pengaruh Profitabilitas, Ukuran Perusahaan dan Kompensasi Rugi Fiskal 
DOI: $\underline{\text { http://dx.doi.org/10.35137/jabk.v6i3.330 }}$

Terhadap Tax Avoidance. Skripsi. Universitas Negeri Padang.

Sari, G., 2014. Pengaruh Corporate Governance, Ukuran Perusahaan, Kompensasi Rugi Fiskal dan Struktur Kepemilikan Terhadap Tax Avoidance (Studi Empiris Pada Perusahaan Manufaktur yang Terdaftar di BEI). Jurnal WRA, Vol.2. No. 2 Oktober 2014.

Sari, N., 2016. Pengaruh Leverage, Profitabilitas, Komisaris Independen dan Likuiditas terhadap Tax Avoidance. Jurnal. Vol, 5 No, 2, 2016.

Suandy, E. 2011. Hukum Pajak,Edisi 5, Jakarta: Salemba Empat.

Sugiyono. 2015. Metode Penelitian Kuantitatif Kualitatif dan $R \& D$. Bandung: Alfabeta.

Suwito, dan Edy. 2013. Analisis Pengaruh Karakteristik Perusahaan Terhadap Tindakan Perataan Laba Yang Dilakukan Oleh Perusahaan Yang Terdaftar di Bursa Efek Jakarta. Simposium Nasional Akuntansi VIII Solo.

Undang-undang No.20 Tahun 2008 tentang Usaha Mikro, Kecil dan Menengah.
Undang - Undang Nomor 28 Tahun 2009 tentang perubahan ketiga atas Undang Undang No. 6 Tahun 1983 tentang ketentuan umum dan tata cara perpajakan (KUP).

Undang - Undang Nomor 36 Tahun 2008 tentang Perubahan Keempat Atas Undang - Undang Nomor 7 Tahun 1983 tentang Pajak Penghasilan.

Viona, S., dan Efriyenti, D. 2018. Analisis Pengaruh Ukuran Perusahaan, Leverage Dan Profitabilitas Terhadap Tax Avoidance Pada Bank Riau Kepri Tbk. Skripsi Universitas Putera Batam.

Waluyo. 2014. Perpajakan Indonesia. Jakarta Selatan : Salemba Empat.

Warsini, S. 2014. Income Shifting Sebagai Reaksi Terhadap Perubahan Tarif Pajak : Deteksi Tindakan Manajemen Laba Dan Manajemen Pajak. Simposium Nasional Akuntansi XVII. 